\title{
THE URGENCY OF CADRE EDUCATION SYSTEM AT DARUNNAJAH CIPINING ISLAMIC BOARDING SCHOOL
}

\author{
Amin Songgirin \\ Universitas Pamulang Kota Tangerang Selatan, Banten \\ dosen01842@unpam.ac.id
}

Diterima 16-07-2020 | Direview 30-08-2020 | Diterbitkan 28-12-2020

\section{Abstract:}

The orientation of Darunnajah Cipining Islamic Boarding School cadre program is to give birth to the best/selected human group, becoming a core force or backbone to defend, support and advance the Darunnajah Cipining Islamic Boarding School called Ashāb al-Najāh. The results of the regeneration process are cadres who have integrity, loyalty, are dedicated, moveable, capable, reliable and militant to realize the ideals of the pesantren and maintain the sustainability of the institution until the Day of Judgment. In the cadre system research at Darunnajah Cipining Islamic Boarding School, using a qualitative approach based on the philosophy of phenomenology, through deep appreciation. The qualitative method tries to understand and interpret the meaning of an event of human behavior interaction in a particular situation according to the researcher's perspective. This approach is directed at the background and the whole individual and does not isolate individuals or institutions into variables or bypotheses, but sees it as part of a whole. The results of this study are the cadre education system at Darunnajah Cipining Islamic Boarding School, which since its establishment has implemented a 16-year compulsory education for cadres, and forges its cadres through education, both formal and direct life practice activities, through training and assignments. Cadre formation in Darunnajah Cipining Islamic Boarding School as a cycle that continues to spin with gradations with several stages. Cadre education is an investment in knowledge, skills and attitudes towards students.

Keywords: Cadre, Regeneration system, Education development, Regeneration process

\begin{abstract}
Abstrak
Orientasi program kader Pesantren Darunnajah adalah untuk melabirkan kelompok manusia terbaik/pilihan, menjadi kekuatan inti atau tulang punggung untuk. membela, menghidupi dan memajukan Pesantren Darunnajah yang disebut "Ashääbunnajāh". Hasil proses kaderisasi ialah kader-kader yang mempunyai integritas, loyalitas, berdedikasi, bergerak, cakap, handal dan
\end{abstract}


militant untuk mewujudkan cita-cita pesantren dan menjaga keberlangsungan lembaganya hingga hari kiamat. Dalam penelitian sistem kader di Pesantren Darunnajah, menggunakan pendekatan kualitatif berdasar pada filsafat fenomenologi, melalui penghayatan mendalam. Metode kualitatif mencoba memahami dan menafsirkan makna suatu peristiwa interaksi tingkah laku manusia dalam situasi tertentu menurut perspektif peneliti. Pendekatan ini diarabkan pada latar dan individu tersebut secara utub dan tidak mengisolasi individu atau lembaga ke dalam variable atau hipotesis, tetapi memandangnya sebagai bagian dari suatu keutuhan. Hasil penelitian ini adalah sistem pendidikan kader di Pesantren Darunnajah, yang sejak berdirinya telah menerapkan wajib belajar 16 tahun bagi kader, dan menempa kadernya melalui pendidikan, baik formal maupun kegiatan praktik bidup secara langsung, melalui pelatihan dan penugasan. Kaderisasi di Pesantren Darunnajah sebagai suatu siklus yang terus berputar dengan gradasi dengan beberapa tahapan. Pendidikan kader, merupakan penanaman pengetabuan, keterampilan, dan sikap kepada santri.

Kata Kunci: Kader, Sistem Kader, Pengembangan Pendidikan, Proses Regenerasi

\section{Introduction}

Cadre education is an important requirement in the world of education. This has been applied since education itself was taught to their offspring or others. Cadre formation is usually identical to an organization that absolutely requires regeneration. Unless the organization is an organization of its own, its members are also themselves. Even a guided organization, where the Chairperson becomes Chairman all his life still needs regeneration for his colleagues. ${ }^{1}$

the problem of Islamic educational institutions is the lack of ability of each Islamic educational institution to prepare leaders collectively. That is, when the central figure or founder has lost his charismatic or passed away, there will be a degradation of human resources, both at the level of education practitioners and the quality of the education of their students. The period of transition or transition to the next generation will be difficult if the families conflict with each other, causing counterproductive things, and difficult to resolve. While the successor to the successor goes slowly. On the other hand educational institutions in economic terms are more established increasingly

\footnotetext{
${ }^{1}$ El-Saha and M. Ishom, Manajemen Kaderisasi Ulama (Ciiputat: Transwacana Jakarta, 2008). P.13
} 
mushrooming. So in order to maintain its setability and existence. Therefore, the purpose of this research was to analyze the urgency of regeneration in the Darunnajah Cipining Islamic Boarding School.

\section{Method}

In this research, researchers used a qualitative approach based on phenomenological philosophy by prioritizing appreciation. The qualitative method seeks to understand and interpret the meaning of an event of human behavior interaction in a particular situation according to the researcher's perspective. $^{2}$ This research uses a qualitative research method by taking a case study at Darunnajah Cipining Islamic Boarding School, Bogor, West Java. ${ }^{3}$ The researcher analyzed how the cadre system was implemented at Darunnajah Cipining Islamic Boarding School, Bogor, which was then made using a SWOT analysis. This research uses three data collection methods; ${ }^{4}$ Observation, ${ }^{5}$ Interview, ${ }^{6}$ and Documentation. ${ }^{7}$

\section{Discussion}

The main purpose of pesantren is to produce cadres. Thus, the device to reach its destination must be prepared. As Habib Chirzin, Director of Islamic Millinium Forum (INFO), said; "There are two main things that are the focus of Abdul Manaf's thoughts in establishing pesantren'. First, the pesantren institution must be an institution that is "tafaqquh fi al-Din" This is what Kiyai Manaf holds firmly to. Pesantren can be advanced, can be modern, can be in the capital but still have to produce scholars. Second, Kyai Manaf sacrifices, endows and fights for facilities and infrastructure with economic support and personal funds.

So when starting to establish an Islamic boarding school, in addition to the aim is to produce scholars (smart in religion), must equip them with knowledge and skills sciences. This idea was expressed by Kamaruzzaman

\footnotetext{
${ }^{2}$ Husnaini Usman, Metodologi Penelitian Sosial (Bandung: Bumi Aksara, 1996). p.81

${ }^{3}$ Norman K Denzin and Yvonna S. Lincoln, Qualitative Research Translated by Dariyatno. Et.Al (Yogyakarta: Pustaka Pelajar, 2009). p. 303

${ }^{4}$ M. Sirozi, Politik Kebijakan Pendidikan Di Indonesia: Peran Tokoh-Tokoh Islam Dalam Penyususnan UU No. 2/1989 (Jakarta: INIS XLIV, 2004). p. 98-99

5 Dewa Ketut Sukardi, Pengantar Pelaksanaan Program Bimbingan Dan Konseling Di Sekolah (Bandung: Remaja Rosdakarya, 2006). p. 153

${ }^{6}$ Lexy J Moleong, Metode Penelitian Kualitatif (Bandung: Remaja Rosdakarya, 2005). p. 186

${ }^{7}$ Sartono Kartodiredjo, Metode-Metode Penelitian Masyarakat (Jakarta: Grafindo, 1986). p. 32
} 
when he wanted to establish Darunnajah. Kamaruzzaman's experience when studying at IAIN Sunan Kalijaga Yogyakarta (now UIN), he saw a junior / senior high school graduate without skills who could not do much, aka unemployed. He also witnessed for himself, a person will be qualified and able to excel if he has religious knowledge and master general knowledge. From this, pesantren are required to teach religious knowledge, general science and skills.

In line with the times, boarding schools have given birth to changes in society. Darunnajah Cipining Islamic Boarding School, has made such changes since its establishment in 1988. The ideas and ideals of the Darunnajah Cipining Islamic Boarding School are based on the intention to advance Muslims and seek the pleasure of Allah, so as to create a civil society. ${ }^{8}$ The founder of the Darunnajah Institution mandates that pesantren should also provide merit to those who are less fortunate with the cross subsidy system. If there are ten santri who pay, one person is free, explained by the leader of Darunnajah Cipining Islamic Boarding School, who is told that they are included in the pesantren cadre program.

Why does the Darunnajah Cipining Islamic Boarding School describe this? Because the geographical location of the pesantren in the village, flanked by mountains, passed by high-powered vehicles, so that the road is never good, and far from urban areas is very difficult to find teachers who want to teach in the pesantren. In addition, many are reluctant to fight in areas far from urban areas. What is also important, is to maintain the sustainability of the institution if its leader dies. ${ }^{10}$

To support this goal, pesantren as an educational institution has always been a place of worship to seek knowledge (talab al-ilmi), a place to seek the pleasure of Allah and to be a source of Islamic knowledge, the language of the Qur'an (Arabic), science, but still have the spirit of the hut. To that end, Darunnajah as an educational environment, provides various instruments for instilling these values. For cognitive goals, these values are conveyed through conducive lectures, directions, upgrading, discussions, formal teaching,

\footnotetext{
${ }^{8}$ Darunnajah Cipining Islamic Boarding Cadre System Bogor Secretariat, "Brief Profile of Pesantren," n.d. p. 6

9 KH. Jamhari Abdul Jalal, Lc, Head of Darunnajah Cipining Islamic Boarding School, November 19, 2015.

10 Darunnajah Cipining Islamic Boarding Cadre System Bogor Secretariat, "Brief Profile of Pesantren.” p. 6
} 
training, assignments, habituation, uswah al-hasanah (exemplary), and conditioning or creating a conducive environment (ijäd al-bícab). So in the process, the philosophy used is, "the method is more important than the material, but the teacher is more important than the method, and the soul of the teacher is more important than the form of the teacher itself'. In this way the true goal of education is expected to be achieved, namely to obtain knowledge that can be practiced so that it becomes part of worship to Allah. ${ }^{11}$

The education process in Darunnajah is community-based, students and teachers live in one dormitory environment. Thus, there was a combination of a culture of values, leadership and the strengthening of systems within a modern institutional framework. All community members in the Darunnajah Islamic Boarding School from Kyai, teachers, students, families, are required to understand, comprehend, live and even fight for these values in their lives as individuals and groups. So Darunnajah Islamic Boarding School education is an effort to change the mindset, attitude, and behavior of students, so that its presence in the community is able to provide as many benefits as possible to others, becoming cadres of the people as well as educators and fighters.

In addition, an effective regeneration process is in its teens. Because this period is a time of mental and character formation. This is the reason for education in Darunnajah is to educate young people in their teen years at the level of junior and senior high. If the age is good then the next period will be easy and will be better. So in Darunnajah there are many activities, the cottage is never empty of activities. Activities will create a dynamic, energetic, will affect the level of speed of thought patterns, attitudes and behavior of students. Finally, they become a superior generation. With 24-hour non-stop activities, it will be seen who has high loyalty, dedication, achievement and integration of values, vision-mission, and discipline. ${ }^{12}$

However, the number of activities is not enough, there is also a need for students to understand the importance of the activities that are followed. With a good and right understanding will foster a call to participate in various activities to the maximum. With understanding, will foster enthusiasm so that students will help, defend and fight for the interests of their huts.

\footnotetext{
${ }^{11}$ Fadjar Malik, Holistika Pemikiran Pendidikan, Ed. Ahmad Barizi (Jakarta: PT Raja Grafindo Persada, 2005). p. 188

12 Muhammad Nur Abdul Hafizh, Mendidik Anak Bersama Rasulullah, Terslated."Manbäj alTarbiyyah al-Nabāwiyyah Li al-Tifl, by Kuswandi Sugiri and Abmad Sanhaji (Bandung: Al Bayan, 1997).p. 35
} 
Darunnajah Islamic Boarding School cadres in developing terms are "Ashäb al-Najäh". Derived from the two root words "Ashäab" and "al-Najäh" meaning "successful friends", or "young generation of Darunnajah". ${ }^{13}$ It is also said as "Rijal al-Ma"bad" ${ }^{\prime \prime 4} b d$ This pesantren cadre program, since the establishment of the Darunnajah Cipining Islamic Boarding School in Bogor, 1988, has been launched by the leader of the pesantren, Jamhari Abdul Jalal. Pesantren provides cadre scholarships based on the hadīth

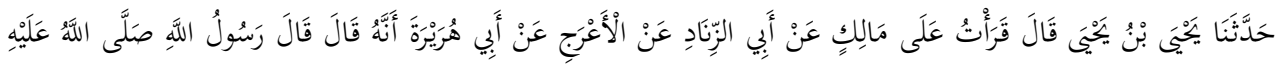

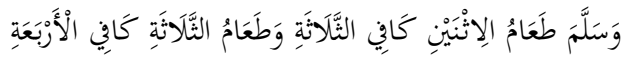

Food for two is enough for three people, and food for three is enough for four people. $^{15}$

Cadres consist of; (1) Darunnajah cadre, is a person who is prepared and appointed by the Darunnajah Foundation to continue the interests and continuity of educational institutions under the auspices of the Darunnajah Foundation, attach to oneself and not be inherited. (2) Cadre of the Ummah, is a person prepared and appointed by the Darunnajah Foundation or other educational institutions for the benefit of the general public and must return and serve the sending institution. ${ }^{16}$

To achieve these cadre goals, the development of a cadre education system curriculum at Darunnajah Cipining Islamic Boarding School was made. What is meant by the development of an educational system curriculum is the existence of a set of elements in the overall component which is applied regularly and interrelated so as to form a totality, both in life in pesantren/caregiving or in madrasas/ education and teaching as well as relating to cadre or regeneration activities in Darunnajah Cipining Islamic Boarding School which refers to Islamic Boarding School Cadre Education System. ${ }^{17}$

\footnotetext{
13 KH. Jamhari Abdul Jalal, Lc, Head of Darunnajah Cipining Islamic Boarding School. November 19, 2015

14 “Manaf Mukhayyar's Biography,” n.d. p. 169-170

${ }^{15}$ Muhammad bin Ismail Al Bukhari, Shabih Bukhari, Second (Beirut: Dar Ibn Katsir, n.d.). No. 3835

16 “SK Darunnajah Foundation No. 2281 / YDN / X / , About Kader Darunnajah,” 2011. p. 2

${ }^{17}$ Ahmad Rosichin, Head of the Darunnajah Cipining Islamic Boarding School Cadre, Bogor period 2010-present, November 18, 2015.
} 
The development of Islamic Boarding School activities, both in terms of nurturing and education is understood as a process to achieve a series of vision, mission, and objectives of the Darunnajah Cipining Islamic Boarding School which has been planned and launched through various joint activities by mobilizing, and functioning of all human resource potential, natural resources, and other resources for continuity in advancing Islamic Boarding School and getting added value that has broad impact. Achievement will be obtained by the existence of effectiveness, efficiency, innovation, and a strong and trustworthy role holder from all components involved in education and care at the Darunnajah Cipining Islamic Boarding School in Bogor. So the system developed is to achieve the vision of the pesantren, namely IMAMA. (Imām or leader, Muttaqie or pious, 'Ālim or knowledgeable/scholars, Muballig or callers/dā'i and 'Āmil or skilled/practice their knowledge). ${ }^{18}$

1. Cadre Recruitment Stage

As stated in the Decree of the Darunnajah Foundation, that Darunnajah cadre is a person prepared and appointed by the Darunnajah Foundation to continue the interests and continuity of educational institutions under the auspices of the Darunnajah Foundation. ${ }^{19}$ Then the Darunnajah cadre is the founding family, alumni of the Tarbiyah al-Mu'allimin/Mu'allimät al-Islamizyah (TMI) Darunnajah or Kulliyyah al-Mu'allimin al-Islamiyyah (KMI) Gontor, teachers, administrators and permanent employees of the Darunnajah Foundation, in charge of six days and has served at least 4 years. ${ }^{20}$

Cadre recruitment carried out and developed by the Darunnajah Cipining Islamic Boarding School through four channels, the first three are related to pesantren cadres and the last one is the ummah cadre. First, the nasab line or descent. This route is specifically for those who are descendants of the children of Manaf, both from direct lines such as children and their offspring or indirectly due to the marriage that gave birth to the next generations. ${ }^{21}$ Second, through the registration path as a teacher and having reached the four-year service period, then the person concerned volunteered to

\footnotetext{
${ }^{18}$ KH. Jamhari Abdul Jalal, Lc, Head of Darunnajah Cipining Islamic Boarding School.

19 "Darunnajah Foundation Decree Number: 2281 / YDN / XI / 2011, Concerning Darunnajah Islamic Boarding School Cadres," 2011. p.2

20 "Darunnajah Foundation Decree Number: 2281 / YDN / XI / 2011, Concerning Darunnajah Islamic Boarding School Cadres.” p. 3

${ }^{21}$ KH. Jamhari Abdul Jalal, Lc, Head of Darunnajah Cipining Islamic Boarding School. November 19, 2015
} 
become a Darunnajah cadre and had verified and fulfilled cadre qualifications. Third, through formal education. Pesantren through the Cadre Bureau distributes brochures in general or specifically to religious leaders, the community, educators, and others, with several requirements. Fourth, ordinary students who study at pesantren with independent fees and no agreement after graduating from education, are merely encouraged to serve or not. Of all the cadres' selection, this third route is the author's discussion. From the four paths, it will be merged into a single unit within the frame of the Darunnajah Cipining Islamic Boarding School cadre. ${ }^{22}$

Input of formal education cadre students is from the age of elementary or equivalent level and advanced level of the first or equivalent, from people who are unable (preferably), ${ }^{23}$ eager to learn, have certain talents, perform on previous education, be ready to be built, ready to undergo a seven- or five-year education and devote himself to pesantren at least five years, either for teaching or other postgraduate duties.

2. Cadre Education Process

Islamic boarding school education is a miniature of community-based education, in which students, teachers, administrators and employees are citizens. They live and live in one area, have rules and laws that must be carried out together for 24 hours and have their respective roles in accordance with their capacities. ${ }^{24}$ Then all of its activities are education, and education has its own value. ${ }^{25}$ Thus, the applicable education is education in a rectangular room or formal education, education in the open or non-formal education, and education in the hostel as representative of the family or informal.

a. Formal Cadre Education

The stage for getting cadres is to hold formal education on a scholarship system. Educational activities are taught in the classroom as is education in general, but there are slight differences in terms of travel time. If education is generally taken in six years for the Tsanawiyah and 'Aliyah levels, then for the education of Darunnajah Cipining Islamic Boarding School cadres take seven years and five years. For those who have graduated from elementary

\footnotetext{
${ }^{22}$ Ibn Khaldūn, Muqaddimah Ibn Khaldūn, (Translation Edition) (Jakarta: Pustaka al-Kautsar, 2001). p. 197

23 "Manaf Mukhayyar's Biography."

${ }^{24}$ Fasli Jalal and Dedi Supriadi, Reformasi Pendidikan Dalam Konteks Otonomi Daerah (Yogyakarta: Adi Cipta, 2001). p. 176

25 Rosichin, Head of the Darunnajah Cipining Islamic Boarding School Cadre, Bogor period 2010-present.
} 
school/MI, the education is seven years, starting from the I'dādì class, class 1 to elementary school. class 3 Madrasah Tsanawiyah, continued class 4 to 6th grade madrasa aliyah. While graduates of SMP/ MTs (Junior High School). His education began with I I'dàdì class, Intensive continued with 4th class to 6 Madrasah 'Áliyah. ${ }^{26}$

If the government at that time launched a nine-year compulsory education program, the Darunnajah Islamic Boarding School since the 2000s has launched a 16-year compulsory education program. Six years of basic education, three years of Tsanawiyah level education, three years of aliyah level education, and four years of college level education. This is intended as a result of the evaluation of the output of cadres who have a Strata 1 education having more role than TMI graduates alone. ${ }^{27}$

At the tertiary level of education or the second phase after graduating from TMI, pesantren in enhancing and developing human resources also collaborate with universities and certain institutions, both at home and abroad, so that student cadres have the opportunity to receive education and apply his knowledge after finishing his studies, is at least the same as the length of his studies. For certain skills, pesantren periodically dispatch their cadres to be positioned in positions that are in accordance with their knowledge.

b. Non-formal Cadre Education

The non-formal cadre education system is not directly integrated with the madrasa curriculum, because it is outside the formal activities of the madrasa. This education is more focused on life skills education (life skills) and integrated in the extracurricular curriculum related to training, organization, and provision of supplies or competencies that must be possessed by all students as prospective cadres of pesantren in the future. ${ }^{28}$ The life skill education focus is given in the first year at the level of I'dadì (preparatory periods) pre-formal education called 'amaliyyah ma'bad (pesantrenan activities). When the student cadre has entered formal education, then the amaliyyah ma 'had will be less and less dense as in I'dā dì class. The I'dādì class is intended to galvanize, form the character of cadre into fanaticism or part of a Islamic

\footnotetext{
${ }^{26}$ Rosichin, Head of the Darunnajah Cipining Islamic Boarding School Cadre, Bogor period 2010-present. 18 November 2015

${ }^{27} \mathrm{KH}$. Jamhari Abdul Jalal, Lc, Head of Darunnajah Cipining Islamic Boarding School. Thursday, November 18, 2015.

${ }^{28}$ H. Trimo, Head of the Darunnajah Cipining Islamic Boarding Business Bureau, 2000present period, November 13, 2015.
} 
Boarding School family. Growing their awareness about ownership and responsibility (send of belonging) to Islamic Boarding School. Growing them to maturity and the most important thing is to grow the values of obedience, loyalty to Islamic Boarding School, because this point is the most important point in the cadre..$^{29}$ So their school is a field practice school, such as; in Islamic boarding schools cooperatives, photocopying, canteens, telephone shops, santri savings, engenering (electricity and water), agriculture, animal husbandry, fisheries, guest house management and welfare (kitchen).

3. Cadre Education Curriculum

Cadre education curriculum development in Darunnajah Cipining Islamic Boarding School covers the background of developing cadre education curriculum based on the curriculum being implemented, synergized with the vision, mission, and objectives of Darunnajah Cipining Islamic Boarding School, referring to the Darunnajah Cipining Islamic Boarding System and based on the aims and objectives of the Foundation Darunnajah. It is intended that Darunnajah Cipining Islamic Boarding School remains at its original destination as an educational institution where the seedlings of al-ulama al'ámilìn wa al-sălihin (ulama who are skilled/ practice their knowledge 'amilun bi al-ilmi and săalih)..$^{30}$ Furthermore, the three main features are formulated in the management of cadre education curriculum development in Darunnajah Cipining Islamic Boarding School into a formal cadre education system and a non-formal cadre education system. The formal cadre education system means the cadre system that has entered into formal education in madrasah Tsanāwiyah and 'Āliyah, while the non-formal cadre education system is a cadre education system integrated in the extracurricular curriculum. The system lasts for seven or five years in an integrated manner in accordance with the input of its cadres. The planning and compilation of the cadre curriculum as mentioned above is spelled out in the formal cadre education curriculum and the nonformal cadre education curriculum. Both are equally important in determining the success or failure of cadre nurseries. So the curriculum must be balanced between the two so that the goals of regeneration are achieved.

3.1. Formal Cadre Education Curriculum

\footnotetext{
${ }^{29} \mathrm{KH}$. Jamhari Abdul Jalal, Lc, Head of Darunnajah Cipining Islamic Boarding School. 19 November 2015

30 "Interpretation of the Vision of Darunnajah Cipining Islamic Boarding, Imām, Muttaqī, 'Ālim, Muballig and 'Āmil (IMAMA) Brief Profile of Darunnajah Cipining Islamic Boarding" (Pesantren Secretariat, n.d.). p. 4
} 
Cadre education planning in Darunnajah Cipining Islamic Boarding School is included in the formal education curriculum. Thus, some teaching materials or subject matter delivered to students integrally contain cadre education. The formal cadre education system is presented for all levels of education, both for Madrasah Tsanāwiyah or Madrasah 'Āliyah. Therefore, in the planning stage of developing a formal cadre education curriculum at Darunnajah Cipining Islamic Boarding School the planning is realized in the form of grouping several categories of material with cadre content so that the goals and direction of the cadres that are in line with Darunnajah Cipining Islamic Boarding School cadre can be achieved. The grouping of material is as follows: ${ }^{31}$ (1) Teacher group subjects, (2) Group of Islamic religious education subjects, ${ }^{32}$ (3) Language subject groups, (4) Arabic subject group subjects, Personality, social and citizenship subjects, Group of science and technology subjects. ${ }^{33}$ Aesthetic subjects. Group of physical, sports and health subjects, ${ }^{34}$ Historical subject groups of civilization and culture.

3.2. Non-formal Cadre Education Curriculum

Non-formal cadre education system is not integrated directly with the madrasa curriculum, because this system is outside the formal activities of the madrasa. In the planning stage, the non-formal cadre education system includes planning cadre activities that are integrated in the extracurricular or stand-alone curriculum, related to training and provision of competencies or competencies that must be possessed by all students as prospective cadres of Darunnajah Cipining Islamic Boarding School in the future. Among the cadre processes in the form of training and competency training that has been designed in the planning stages of cadre education curriculum development in the Darunnajah Cipining Islamic Boarding School and adjusted the Darunnajah Foundation cadre system is leadership training, organizational management training, communication skills training, communication skills, cooperation in analyzing problems, training provides solutions or solutions to problems, social solidarity, entrepreneurship, and the provision of skills in the

\footnotetext{
31 "Draft Curriculum for Learning from the Cipunn Darunnajah Islamic Boarding School in 2013/2014," n.d.

${ }^{32}$ Yamansyah, Sejarah Pendidikan Islam (Jakarta: Kencana Prenada Media Grup, 2007). p. 242

33 Budi Rahardjo, Memahami Teknologi Informasi (Jakarta: PT Elex Media Komputindo, Gramedia, 2002).

${ }^{34}$ M. Quraish Shihab, Tafsir Al-Misbah: Messages, Impressions and Harmony of the Qur'an, Cet 1, vol. Vol 3 (Jakarta: Lentera Hati, 2001). p. 33
} 
form of life skills which are the abilities possessed by students to face various challenges in their life's journey. ${ }^{35}$

\subsection{Cadre Management in Darunnajah Cipining Islamic Boarding School}

Darunnajah Cipining Islamic Boarding School Organization has undergone changes several times that are adjusted to the conditions and needs that are intended to answer or accommodate various needs and problems in a professional direction. There are at least ten bureaus, representatives of pesantren leaders or caretakers to carry out their functions. ${ }^{36}$

Between the Bureau and the others are interrelated in fostering and escorting pesantren cadres. The bureaus referred to are as follows: Educational Bureau, Santri Care Bureau, Pesantren Finance Bureau, Business Bureau, Household Bureau, Da'wah and Public Relations Bureau, Cadre Bureau, Santri's Scouting and Achievement Development Bureau, Information Technology and Communication Bureau and Resources Bureau Teachers and Santri. ${ }^{37}$

At the stage of organizing the development of educational curriculum cadres of each bureau carry out their functions in accordance with the provisions. ${ }^{38}$ The important role in cadre education curriculum planning is the cadre cadre. This bureau has an important role in developing cadres. Consolidating the activities of cadres developed in the bureaus in the pesantren. Stages of organizing are in this bureau. The escort since recruitment, the education process, the educational progress and the finalization of student cadres are in this bureau.

In the stage of organizing the development of cadre education curriculum in Darunnajah Cipining Islamic Boarding School rests on all bureaus in the pesantren with the most important being the Cadre Bureau as an umbrella or its vehicle. The functions of other bureaus as elements that are not separate from one another's education, are interrelated, interconnected and mutually reinforcing. In principle formal education is within the reach of the education bureau, while non-formal education is in nine bureaus that work

\footnotetext{
${ }^{35}$ Rosichin, Head of the Darunnajah Cipining Islamic Boarding School Cadre, Bogor period 2010-present. 18 November 2015

${ }^{36}$ KH. Jamhari Abdul Jalal, Lc, Head of Darunnajah Cipining Islamic Boarding School. 18 November 2015

${ }^{37}$ Jamhari Abdul Jalal, "Paper on Profile of Pesantren Darunnajah Cipining, Structure of Pesantren Bureau,” 2014.

38 "Structure of the Work Program of the Darunnajah Islamic Boarding School in Cipining, Bogor, West Java in 2015-2016," n.d., 2015-16.
} 
together. Bureau one with each other to give color to the culture of cadres Darunnajah Cipining Pesantren, even all pesantren residents are obliged to bring the cadre climate. ${ }^{39}$

All elements involved in the regeneration process mentioned above, carry out the tasks of regeneration in the integrated education system in the pesantren by combining the madrasa system and the pesantren. It is hoped that the merging of the two education systems will give students complete education, so that all aspects of cadre education can be covered. Namely the intellectual, spiritual, social, emotional, creative and innovative aspects. In connection with this achievement, the learning activities of students both in madrasas and in the dormitory refer to the Islamic Boarding Schools Cadre System by developing cadre education management curriculum developed. All elements or bureaus in the organizational system contribute and are directly involved in the regeneration process, presenting a regeneration culture by implementing the principles and activities. ${ }^{40}$

\section{Conclusion}

1. The regeneration program is the nature of all human beings to maintain their survival through marital relations. Seeing this intimacy, Islamic educational institutions are required to cadre as an institutional strategy to produce quality cadres. The orientation of the Darunnajah Pesantren cadre program is to give birth to the best / selected human group, becoming a core force or backbone to defend, support and advance the Darunnajah Pesantren called Asḥäb al-Najäh .

2. The results of the regeneration process are cadres who have integrity, loyalty, are dedicated, moveable, capable, reliable and militant to realize the ideals of the pesantren and maintain the sustainability of the institution until the Day of Judgment. Gait cadre is expected to color from all pesantren's nadis, because they have received certain education and training.

3. A cadre has the main task of developing institutions, while at the same time

\footnotetext{
${ }^{39} \mathrm{KH}$. Jamhari Abdul Jalal, Head of Cipining Darunnajah Islamic Boarding School in Bogor, Interview, Bogor, November 19, 2015

40 Zamroni, Percikan Pemikiran Pendidikan Mubammadiyah (Yogyakarta: Penerbit Ombak, 2014). p. 111
} 
avoiding ideology from possible distortion. Therefore, besides the cadre must be physically active, he must continually study the ideology formulation in relation to the tasks in the organization and its supporting sciences.

\section{Daftar Pustaka}

Bukhari, Muhammad bin Ismail Al. Shabih Bukhari. Second. Beirut: Dar Ibn Katsir, n.d.

Darunnajah Cipining Islamic Boarding Cadre System Bogor Secretariat. "Brief Profile of Pesantren," n.d.

"Darunnajah Foundation Decree Number: 2281 / YDN / XI / 2011, Concerning Darunnajah Islamic Boarding School Cadres," 2011.

Denzin, Norman K, and Yvonna S. Lincoln. Qualitative Research Translated by Dariyatno. Et.Al. Yogyakarta: Pustaka Pelajar, 2009.

"Draft Curriculum for Learning from the Cipunn Darunnajah Islamic Boarding School in 2013/2014," n.d.

El-Saha, and M. Ishom. Manajemen Kaderisasi 'Ulama. Ciiputat: Transwacana Jakarta, 2008.

Fadjar Malik. Holistika Pemikiran Pendidikan. Ed. Ahmad Barizi. Jakarta: PT Raja Grafindo Persada, 2005.

Fasli Jalal, and Dedi Supriadi. Reformasi Pendidikan Dalam Konteks Otonomi Daerah. Yogyakarta: Adi Cipta, 2001.

H. Trimo. Head of the Darunnajah Cipining Islamic Boarding Business Bureau, 2000-present period, November 13, 2015.

Ibn Khaldūn. Muqaddimah Ibn Khaldūn. (Translation Edition). Jakarta: Pustaka al-Kautsar, 2001.

"Interpretation of the Vision of Darunnajah Cipining Islamic Boarding, Imām, Muttaqī' 'Ālim, Muballig and 'Āmil (IMAMA) Brief Profile of Darunnajah Cipining Islamic Boarding.” Pesantren Secretariat, n.d.

Jamhari Abdul Jalal. "Paper on Profile of Pesantren Darunnajah Cipining, Structure of Pesantren Bureau," 2014.

Kartodiredjo, Sartono. Metode-Metode Penelitian Masyarakat. Jakarta: Grafindo, 1986.

KH. Jamhari Abdul Jalal, Lc. Head of Darunnajah Cipining Islamic Boarding School, November 19, 2015.

"Manaf Mukhayyar's Biography," n.d. 
Moleong, Lexy J. Metode Penelitian Kualitatif. Bandung: Remaja Rosdakarya, 2005.

Muhammad Nur Abdul Hafizh. Mendidik Anak Bersama Rasulullah, Terslated. "Manbäj al-Tarbiyyah al-Nabäwiyyah Li al-Tifl, by Kuswandi Sugiri and Ahmad Sanhaji. Bandung: Al Bayan, 1997.

Rahardjo, Budi. Memahami Teknologi Informasi. Jakarta: PT Elex Media Komputindo, Gramedia, 2002.

Rosichin, Ahmad. Head of the Darunnajah Cipining Islamic Boarding School Cadre, Bogor period 2010-present, November 18, 2015.

Shihab, M. Quraish. Tafsir Al-Misbah: Messages, Impressions and Harmony of the Qur'an. Cet 1. Vol. Vol 3. Jakarta: Lentera Hati, 2001.

Sirozi, M. Politik Kebijakan Pendidikan Di Indonesia: Peran Tokoh-Tokob Islam Dalam Penyususnan UU No. 2/1989. Jakarta: INIS XLIV, 2004.

"SK Darunnajah Foundation No. 2281 / YDN / X / , About Kader Darunnajah,” 2011.

"Structure of the Work Program of the Darunnajah Islamic Boarding School in Cipining, Bogor, West Java in 2015-2016," n.d.

Sukardi, Dewa Ketut. Pengantar Pelaksanaan Program Bimbingan Dan Konseling Di Sekolah. Bandung: Remaja Rosdakarya, 2006.

Usman, Husnaini. Metodologi Penelitian Sosial. Bandung: Bumi Aksara, 1996.

Yamansyah. Sejarah Pendidikan Islam. Jakarta: Kencana Prenada Media Grup, 2007.

Zamroni. Percikan Pemikiran Pendidikan Mubammadiyah. Yogyakarta: Penerbit Ombak, 2014. 